\title{
Front line demonstrations on management of Alkali water through gypsum in Ambala (Haryana)
}

\author{
Guru Prem, Amit Kumar, Ramesh Kumar and Upasana Singh
}

MEMBERS OF RESEARCH FORUM:

Corresponding author :

Guru Prem, Krishi Vigyan Kendra,

Ambala (Haryana) India

Email: gpgrover79@gmail.com

Co-authors :

Amit Kumar, Ramesh Kumar

and Upasana Singh, Krishi Vigyan

Kendra, Ambala (Haryana) India
Received : 24.09.2018; Revised : 10.11.2018; Accepted : 21.11.2018

\section{Summary}

The front line demonstration on management of Alkali water through gypsum in wheat was conducted. Each demonstration was of 0.4 ha area and gypsum was supplied as critical input for partial fulfilment. The total 99 water samples were collected from 11 villages, which lie in 5 blocks of Ambala district. The total 40 front line demonstrations on gypsum application in 16 hectares were conducted at farmers' field, during the year 2014-15 to 2017-18 in different villages of district Ambala. The grain yield of wheat during study under demonstrated plots was varied from 41.25 to $46.00 \mathrm{q} / \mathrm{ha}$, while it was 35.00 to $40.00 \mathrm{q} / \mathrm{ha}$ under farmer practice. Gypsum application plots have higher wheat yield. On the basis of extension gap, the farmers were motivated to adopt recommended package of practices to reduce the extension gap and to increase their grain yield under alkali water irrigation. The higher additional returns and effective gain obtained under demonstrations could be due to improved technologies such as management of alkali irrigation water, better nutrient management and scientific monitoring in demonstration plots. The highest incremental B:C ratio was 6.32 during the year 2016. It depends on grain yield and MSP. Overall average of incremental B: C ratio was found to be 5.10:1.

Key words : Alkali water, Gypsum, Front line demonstrations, Extension gap, Economic analysis

How to cite this article : Prem, Guru, Kumar, Amit, Kumar, Ramesh and Singh, Upasana (2018). Front line demonstrations on management of Alkali water through gypsum in Ambala (Haryana). Asian J. Soil Sci., 13 (2) : 131-135 : DOI : 10.15740/HAS/AJSS/13.2/131-135. 